\title{
Kinerja Guru dalam Menganalisis Hasil Evaluasi pada Pembelajaran Pendidikan Jasmani dan Kesehatan di Sekolah Menengah Kejuruan
}

\author{
Moh Indra Kurnia Hadiputra ${ }^{1}$, M. E. Winarno ${ }^{1}$, Sugiharto $^{1}$ \\ ${ }^{1}$ Pendidikan Olahraga-Universitas Negeri Malang
}

INFO ARTIKEL
Riwayat Artikel:
Diterima: $26-07-2019$
Disetujui: $19-09-2019$
Kata kunci:
teacher performance;
physical education and health
learning;
vocational high school;
kinerja guru;
pembelajaran pendidikan jasmani
dan kesehatan;
sekolah menengah kejuruan

Alamat Korespondensi:

Moh Indra Kurnia Hadiputra

Pendidikan Olahraga

Universitas Negeri Malang

Jalan Semarang 5 Malang

E-mail: muhammad06indra@gmail.com

Guru memiliki peran penting mewujudkan tujuan pendidikan. Guru merupakan tenaga profesional yang bertugas merencanakan, melaksanakan, dan mengevaluasi hasil pembelajaran siswa. Seperti yang dijelaskan dalam ("Undang-undang Republik Indonesia Nomor 14 tentang guru dan dosen," 2005) ayat (1) guru berkewajiban: merencanakan pembelajaran, melaksanakan proses pembelajaran yang bermutu, menilai, dan mengevaluasi hasil pembelajaran. Hal ini juga berlaku pada guru Pendidikan Jasmani dan Kesehatan, (Baan, 2012) guru Pendidikan Jasmani dan Kesehatan harus mampu menilai dan mengevaluasi hasil seluruh proses pembelajaran. (Gaytan \& Mcewen, 2007) menyatakan bahwa penilaian merupakan cara yang tepat untuk tolak ukur siswa. Oleh karena itu, pendidik harus menetapkan tujuan penilaian, kriteria yang dinilai, dan hasil yang dimaksudkan dalam penilaian sebelum metode penilaian dapat dicapai. Tujuan utama penilaian adalah untuk melihat belajar siswa, meningkatkan kualitas akademik, dan meningkatkan pembelajaran. Selama ini, pembelajaran Jasmani dan Kesehatan masih belum sesuai harapan, hal tersebut diketahui bahwa Pendidikan Jasmani dan Kesehatan dipandang kurang penting dibandingkan pembelajaran lain dan masih banyak orang beranggapan guru Pendidikan Jasmani dan Kesehatan merupakan pekerjaan yang mudah. Akan tetapi, di sisi lain masih banyak guru Pendidikan Jasmani dan Kesehatan melaksanakan tugasnya tidak sesuai dengan tugas pokok atau kurang serius dalam menyelesaikan tugas.

Tugas seorang guru Pendidikan Jasmani dan Kesehatan tidak hanya menyampaikan materi kepada siswa, tetapi juga harus mengevaluasi dan melaporkan hasil evaluasinya. (Eraslan, 2013) menjelaskan bahwa keterbatasan kemampuan dan wawasan guru mengenai sistem penilaianpun dapat terjadi. Selain itu, hasil penelitian (Markle \& Banion, 2014) menunjukkan masih sangat sedikit guru melaksanakan penilaian pengetahuan dengan baik di lapangan. Seorang guru Pendidikan Jasmani dan Kesehatan harus merencanakan evaluasi dan menganalisis hasil evaluasi siswa dengan baik. (Stufflebeam \& Coryn, 2014) menyatakan bahwa evaluasi adalah proses sistematis menggambarkan, memperoleh, pelaporan, dan mendeskripsikan dan menghakimi informasi tentang manfaat beberapa objek, layak, kejujuran, kelayakan, keselamatan, signifikansi, dan atau ekuitas . 
(Wood, 2010) evaluasi didefinisikan sebagai penilaian pencapaian tujuan melalui tiga fase, yaitu pengumpulan data, analisis data, dan pengambilan keputusan. Evaluasi dalam Pendidikan Jasmani dan Kesehatan yang dimakud tersebut, melingkupi tiga aspek, yaitu evaluasi aspek sikap, pengetahuan, dan keterampilan. Menurut (Wang, Wang, \& Huang, 2012) guru dan orangtua dapat menyadari bahwa prestasi akademik dan aktivitas fisik saling melengkapi satu sama lain dan aktivitas fisik yang memadai tidak bisa hanya meningkatkan kesehatan mental dan fisik siswa, tetapi dapat meningkatkan kemampuan belajar mereka juga.

Berdasarkan hasil penelitian (Lleixà, González-Arévalo, \& Braz-Vieira, 2016) orientasi Pendidikan Jasmani yaitu menuju gaya hidup sehat, potensi untuk mengembangkan interaksi sosial dan pengalaman yang berkarakter membuatnya sangat cocok untuk memperoleh kompetensi kunci. Kompetensi paling sering masuk dalam program Pendidikan Jasmani belajar di sini adalah sosial dan keterampilan kewarganegaraan, kemandirian dan inisiatif pribadi, belajar untuk belajar, dan pengetahuan dan interaksi dengan dunia fisik. Selain itu, (Winarno, 2014) menyatakan untuk bidang studi Pendidikan Jasmani, titik tekan penilaian didasarkan pada kemampuan psikomotor, namun tidak mengabaikan kemampuan kognitif dan afektif. Hasil evaluasi merupakan informasi yang penting untuk perbaikan proses pembelajaran sehingga diperlukan analisis hasil evaluasi yang optimal, jika hal ini tidak dilakukan dengan baik akan berpengaruh terhadap umpan balik dari proses pembelajaran yang telah dilakukan dan hasil evaluasi tidak menggambarkan kemampuan siswa yang sebenarnya. Selain itu, dampak langsung terhadap siswa dapat menurunkan motivasi siswa dalam pelaksanaan pembelajaran yang berpengaruh terhadap penurunan kesegaran jasmani siswa, (Zhang et al., 2011) pada program pembelajaran bahwa kinerja dari program pembelajaran dinilai dari beberapa aspek, salah satunya yakni service dinilai dari perhatian dan minat siswa.

Pelaksanaan evaluasi yang belum dilaksanakan dengan baik khususnya pada analisis hasil evaluasi maka akan mengakibatkan beberapa dampak tehadap guru maupun siswa. (Popham, 2009) Penilaian merupakan salah satu aspek penting pada proses pendidikan. Penilaian merupakan langkah untuk menghimpun berbagai informasi yang digunakan untuk penentuan kebijakan proses pembelajaran. (Popham, 2009) penilaian memiliki peran besar dalam menentukan kesuksesan pendidikan, penilaian yang baik memberikan dampak pada proses pembelajaran. Dampak menurunnya profesionalisme guru dapat terjadi jika dilakukan evaluasi atau supervisi dari sekolah maupun pengawas karena tugas pokok guru tidak dijalankan dengan baik. Selain itu, guru tidak mendapatkan umpan balik pada pembelajaran yang telah dilakukan karena hasil evaluasi tidak benar-benar menggambarkan hasil pembelajaran yang telah dilakukan. Jika guru tidak melakukan analisis hasil evaluasi pada pembelajarannya maka siswa tidak mengetahui aspek yang akan dievaluasi oleh guru sehingga menurunkan motivasi belajar siswa tersebut, jika motivasi siswa menurun maka kebugaran jasmani siswa akan menurun juga karena aktivitas gerak siswa kurang maksimal. Selain itu, jika penetapan nilai dilakukan kurang baik maka hasil yang didapatkan tidak menggambarkan kemampuan siswa yang sebenarnya karena hasil evaluasi yang didapat kurang tepat.

\section{METODE}

Pendekatan yang dilakukan dalam penelitian ini adalah kualitatif dengan menggunakan desain studi kasus. Data yang diperoleh pada penelitian ini disajikan dalam bentuk narasi dan pemaparan hasil penelitian digunakan untuk menjelaskan masalah yang diteliti. Penelitian ini mengevaluasi perencanaan dan analisis hasil evaluasi pada pembelajaran Pendidikan Jasmani dan Kesehatan yang dilakukan oleh guru Pendidikan Jasmani dan Kesehatan di SMK kota Blitar sesuai dengan Permendiknas yang telah ditetapkan.

Penelitian ini menggunakan dua sumber data, yaitu sumber data primer dan sekunder. Sumber data primer pada penelitian ini yaitu guru Pendidikan Jasmani dan Kesehatan. Peneliti mengambil data primer dengan cara melakukan wawancara terhadap guru Pendidikan Jasmani dan Kesehatan dan hasil wawancara tersebut dijadikan peneliti sebagai data primer pada penelitian ini. Sumber data sekunder yang dimiliki oleh guru Pendidikan Jasmani dan Kesehatan berupa rancangan pelaksanaan pembelajaran (RPP), skor penilaian pada aspek kognitif, afektif, dan psikomotor. Hasil analisis skor penilaian pada ketiga aspek tersebut, dijadikan peneliti sebagai sumber data sekunder. Kedua data tersebut dimasukan dalam laporan penelitian, data primer sebagai data utama yang diperkuat oleh data sekunder atau data sekunder sebagai pengecekan keabsahan dari data primer.

\section{HASIL}

Penelitian yang dilakukan di SMK kota Blitar tentang analisis penilaian siswa yang dilakukan oleh guru Pendidikan Jasmani dan Kesehatan dengan melakukan beberapa kegiatan, yaitu wawancara kepada guru Pendidikan Jasmani dan Kesehatan, studi pada dokumen guru Pendidikan Jasmani dan Kesehatan, dan memberikan angket kepada siswa memperoleh beberapa temuan, bahwa seluruh guru Pendidikan Jasmani dan Kesehatan di SMK kota Blitar menetapkan aspek sikap sebagai salah satu sasaran penilaian dalam pembelajaran Pendidikan Jasmani dan Kesehatan. Guru tersebut melaksanakan penilaian aspek sikap dengan cara mengamati seluruh siswa selama pembelajaran berlangsung. Akan tetapi, guru Pendidikan Jasmani dan Kesehatan memberikan nilai aspek sikap secara langsung, tidak menunjukkan proses yang telah dijelaskan sebelumnya pada dokumen rancangan pelaksanaan pembelajaran (RPP). Pada dokumen tersebut dijelaskan bahwa aspek penilaian sikap memiliki beberapa poin dan proses menganalisis nilai sikap dari beberapa poin yang telah ditetapkan, hasil dari poin-poin dan juga proses analisis penilaian aspek sikap tersebut tidak muncul pada dokumen penilaian yang dimiliki masing-masing guru Pendidikan Jasmani dan Kesehatan di SMK kota Blitar. 
Guru Pendidikan Jasmani dan Kesehatan di SMK kota Blitar juga menetapkan aspek pengetahuan sebagai salah satu sasaran penilaian dalam pembelajaran Pendidikan Jasmani dan Kesehatan. Guru tersebut melaksanakan penilaian aspek pengetahuan secara resiprokal kepada seluruh siswanya, sebelumnya telah mempersiapkan beberapa soal yang diberikan kepada seluruh siswa. Akan tetapi, guru Pendidikan Jasmani dan Kesehatan tersebut memberikan nilai aspek pengetahuan secara langsung tidak menunjukkan proses yang telah dijelaskan sebelumnya pada dokumen rancangan pelaksanaan pembelajaran (RPP), pada dokumen guru tersebut diterangkan bahwa aspek penilaian pengetahuan memiliki beberapa soal dan juga proses menganalisis nilai pengetahuan dari beberapa soal yang telah diberikan kepada siswa, hasil dari soal yang telah diberikan kepada seluruh siswa dan juga proses analisis penilaian aspek pengetahuan tersebut tidak muncul pada dokumen penilaian yang dimiliki masing-masing guru Pendidikan Jasmani dan Kesehatan di SMK kota Blitar.

Guru Pendidikan Jasmani dan Kesehatan di SMK kota Blitar menetapkan aspek keterampilan sebagai salah satu sasaran penilaian dalam pembelajaran Pendidikan Jasmani dan Kesehatan disamping aspek sikap dan pengetahuan. Guru tersebut melaksanakan penilaian aspek keterampilan dengan cara pemberian tes praktik atau unjuk kerja kepada seluruh siswanya bedasarkan materi yang telah diajarkan, sebelumnya guru telah mempersiapkan instrumen tes praktik atau unjuk kerja pada materi yang diujikan kepada seluruh siswanya. Akan tetapi, guru Pendidikan Jasmani dan Kesehatan memberikan nilai pada aspek keterampilan secara langsung tidak menunjukkan proses yang telah dijelaskan sebelumnya pada dokumen rancangan pelaksanaan pembelajaran (RPP), pada dokumen guru tersebut diterangkan bahwa aspek penilaian keterampilan memiliki beberapa indikator penilaian dan juga proses menganalisis nilai keterampilan dari beberapa indikator yang telah ditetapkan oleh guru, hasil dari tiap indikator penilaian aspek keterampilan setiap siswa dan juga proses analisis penilaian aspek keterampilan tersebut tidak muncul pada dokumen penilaian yang dimiliki masing-masing guru Pendidikan Jasmani dan Kesehatan di SMK kota Blitar.

Seluruh guru Pendidikan Jasmani dan Kesehatan di SMK kota Blitar memberikan nilai akhir sebagai nilai rapor siswa pada pembelajaran Pendidikan Jasmani dan Kesehatan. Seluruh guru menetapkan nilai akhir siswa berdasarkan nilai-nilai yang diperoleh dari setiap aspek penilaian (aspek sikap, pengetahuan, dan keterampilan). Dari ketiga aspek tersebut, guru telah menetapkan bobot dari masing-masing aspek penilaian dan terdapat tiga sekolah yang menetapkan nilai akhir siswa dengan ditambahkan hasil penilaian UTS dan UAS. Selain hal tersebut, guru juga telah merencanakan analisis penetapan nilai akhir seluruh siswa, tetapi hanya tiga dari tujuh sekolah yang merencanakan analisis penilaian sesuai dengan masing-masing bobot yang telah ditetapkan oleh masing-masing guru, sisanya yaitu empat sekolah merencanakan analisis penilaian menggunakan rumus rerata dari ketiga aspek penilaian (aspek sikap, pengetahuan, dan keterampilan). Pada saat penetapan nilai akhir siswa, seluruh guru Pendidikan Jasmani dan Kesehatan di SMK kota Blitar melakukan analisis penilaian akhir sesuai dengan perencanaan yang telah dibuat sebelumnya.

\section{PEMBAHASAN}

\section{Penilaian Aspek Sikap}

Guru Pendidikan Jasmani dan Kesehatan di SMK kota Blitar secara keseluruhan telah melaksanakan penilaian aspek sikap terhadap siswanya, hal tersebut dapat dilihat dari hasil angket siswa yang memperoleh pada masing-masing sekolah. Selain itu, pada dokumen RPP guru juga terdapat beberapa nilai-nilai yang dijadikan tolak ukur untuk penilaian aspek sikap di masingmasing sekolah. Pelaksanaan aspek sikap, secara keseluruhan dilaksanakan dengan cara melakukan pengamatan kepada siswanya pada saat pembelajaran berlangsung, hanya SMK Negeri yang menambahkan hasil presensi siswa sebagai tolak ukur penilaian akhir pada aspek sikap, sedangkan SMK Swasta hanya hasil pengamatan yang dijadikan tolak ukur penilaian aspek sikap. Hal tersebut seperti yang dijelaskan (Hanna \& Dettmer, 2003) aspek afektif merupakan tujuan pebelajaran mengenai keadaan emosi atau perasaan, tujuan tersebut menyangkut minat, sikap, nilai, dan penghargaan. Selain itu, penilaian aspek sikap dilaksanakan dengan cara melakukan pengamatan pada saat siswa melaksanakan pembelajaran, pelaksanaan ini sesuai dengan yang dijelaskan (Basuki \& Hariyanto, 2016) Penilaian dapat berupa kuisioner atau lembar hasil observasi, dan penilaian afektif, meliputi pengamatan sikap, minat, nilai, moral dan konsep diri, menurut (Uno \& Koni, 2016) penilaian sikap dapat dilakukan dengan beberapa teknik, antara lain teknik observasi perilaku, pertanyaan langsung dan laporan pribadi, kemudian dijelaskan oleh (Allen \& Friedman, 2010) cara yang paling efektif untuk menilai aspek sikap dengan cara menilai tujuan, mengamati perilaku, dan ekspresi pelajar.

Hasil analisis dokumen guru berupa RPP dan penilaian menunjukkan bahwa pelaksanaan tersebut tidak menggambarkan kesesuaian antara perencanaan terhadap hasil penilaian aspek sikap yang telah dibuat oleh guru tersebut. Guru Pendidikan Jasmani dan Kesehatan di SMK kota Blitar merencanakan penilaian aspek sikap, tetapi poin-poin aspek sikap yang telah rencanakan tidak terdapat pada dokumen hasil penilaian guru tersebut, dokumen penilaian guru hanya terdapat nilai akhir aspek sikap siswa. Berdasarkan hal tersebut dapat diketahui bahwa proses penilaian aspek sikap dari perencanaan sampai penilaian akhir tidak menggambarkan kesesuaian dengan yang dijelaskan (Peraturan Menteri Pendidikan dan Kebudayaan, 2016) bahwa penilaian harus dilakukan secara sistematis, berarti penilaian dilakukan secara berencana dan bertahap dengan mengikuti langkah-langkah baku. Beracuan kriteria, berarti penilaian didasarkan pada ukuran pencapaian kompetensi yang ditetapkan. 


\section{Penilaian Aspek Pengetahuan}

Guru Pendidikan Jasmani dan Kesehatan di SMK kota Blitar telah melaksanakan penilaian aspek pengetahuan, hal tersebut dapat dilihat dari hasil angket siswa pada masing-masing sekolah. Pada dokumen RPP guru, seluruh guru Pendidikan Jasmani dan Kesehatan kota Blitar melaksanakan penilaian aspek pengetahuan dengan teknik resiprokal. Hal tersebut sesuai dengan yang dijelaskan (Hanna \& Dettmer, 2003) aspek kognitif merupakan bagian keterampilan intelektual yang melibatkan daya ingatan dan proses berpikir, dan juga yang dijelaskan (Haryati, 2008) aspek kognitif berhubungan dengan kemampuan berpikir termasuk didalamnya kemampuan memahami, menghafal, mengaplikasi, menganalisis, mensintesis dan kemampuan mengevaluasi.

Dokumen guru berupa RPP dan penilaian menunjukkan bahwa pelaksanaan penilaian asspek pengetahuan tersebut tidak menggambarkan kesesuaian antara perencanaan terhadap hasil penilaian aspek pengetahuan yang telah dibuat oleh seluruh guru tersebut. Proses penilaian pengetahuan yang telah direncanakan tidak terdapat pada dokumen hasil penilaian guru tersebut, dokumen penilaian guru secara keseluruhan hanya terdapat nilai akhir aspek pengetahuan. Berdasarkan hal tersebut dapat diketahui bahwa proses penilaian aspek pengetahuan dari perencanaan sampai penilaian akhir tidak menggambarkan kesesuaian dengan yang dijelaskan (Peraturan menteri pendidikan dan kebudayaan, 2016) bahwa penilaian harus dilakukan secara sistematis, berarti penilaian dilakukan secara berencana dan bertahap dengan mengikuti langkah-langkah baku. Beracuan kriteria, berarti penilaian didasarkan pada ukuran pencapaian kompetensi yang ditetapkan.

\section{Penilaian Aspek Keterampilan}

Guru Pendidikan Jasmani dan Kesehatan di SMK kota Blitar telah membuat perencanaan penilaian aspek keterampilan, hal tersebut dapat dilihat dari hasil angket siswa pada masing-masing sekolah. Pada dokumen RPP guru, penilaian aspek keterampilan dilaksanakan dengan cara pemberian tes praktik kepada siswa, hal tersebut sesuai dengan yang dijelaskan (Basuki \& Hariyanto, 2016) bahwa untuk melaksanakan pengukuran hasil belajar psikomotor guru membuat perangkat instrumen untuk mengamati kinerja peserta didik, soal hasil belajar psikomotor dapat berupa lembar kerja, lembar tugas, perintah kerja dan juga dijelaskan. Menurut (Sudjana, 2014) hasil belajar psikomotorik tampak dalam bentuk keterampilan dan kemampuan bertindak individu.

Akan tetapi, berdasarkan analisis dokumen dan penilaian secara keseluruhan pelaksanaan aspek keterampilan yang telah rencanakan tidak terdapat pada dokumen hasil penilaian guru tersebut, dokumen penilaian guru hanya terdapat nilai akhir aspek keterampilan. Berdasarkan hal tersebut dapat diketahui bahwa proses penilaian aspek keterampilan dari perencanaan sampai penilaian akhir tidak menggambarkan kesesuaian dengan (Peraturan Menteri Pendidikan dan Kebudayaan, 2016) bahwa penilaian harus dilakukan secara sistematis, berarti penilaian dilakukan secara berencana dan bertahap dengan mengikuti langkah-langkah baku. Beracuan kriteria, berarti penilaian didasarkan pada ukuran pencapaian kompetensi yang ditetapkan.

\section{Nilai Akhir Siswa}

Guru Pendidikan Jasmani dan Kesehatan di SMK kota Blitar memberikan penilaian akhir sebagai nilai rapor siswa, hal tersebut dapat dilihat dari hasil angket siswa pada masing-masing sekolah. Penilaian akhir tersebut dianalisis dari hasil penilaian aspek sikap, pengetahuan dan keterampilan, dan analisis tersebut sesuai dengan perencanaan yang telah dibuat oleh guru. Berdasarkan hal tersebut dapat diketahui bahwa proses penilaian akhir siswa dari perencanaan sampai penilaian akhir menggambarkan kesesuaian dengan yang dijelaskan (Peraturan Menteri Pendidikan dan Kebudayaan, 2016) bahwa penilaian harus dilakukan secara sistematis, berarti penilaian dilakukan secara berencana dan bertahap dengan mengikuti langkah-langkah baku. Penilaian didasarkan pada ukuran pencapaian kompetensi yang ditetapakan dan menurut (Kankam, Bordoh, Eshun, Bassaw, \& Korang, 2015) diharapkan seorang siswa dapat mengembangkan kemampuannya untuk kepentingan masyarakat. Dengan demikian, seorang guru harus menguji dengan cara yang benar dalam hal pengetahuan, keterampilan, nilai-nilai, dan sikap.

\section{SIMPULAN}

Seluruh guru Pendidikan Jasmani dan Kesehatan di SMK kota Blitar menetapkan aspek sikap sebagai aspek penilaian, dan seluruh guru telah menetapkankan poin-poin untuk penilaian aspek sikap pada siswanya masing-masing, guru tersebut melaksanakan penilaian aspek sikap dengan cara mengamati seluruh siswa selama pembelajaran berlangsung. Akan tetapi secara keseluruhan guru Pendidikan Jasmani dan Kesehatan tersebut memberikan nilai aspek sikap secara langsung tidak menunjukkan proses yang telah dijelaskan sebelumnya pada dokumen rancangan pelaksanaan pembelajaran (RPP), pada dokumen guru tersebut diterangkan bahwa aspek penilaian sikap memiliki beberapa poin dan juga proses menganalisis nilai sikap dari beberapa poin yang telah ditetapkan, hasil dari poin-poin dan juga proses analisis penilaian aspek sikap tersebut tidak muncul pada dokumen penilaian yang dimiliki masing-masing guru Pendidikan Jasmani dan Kesehatan di SMK kota Blitar.

Seluruh guru Pendidikan Jasmani dan Kesehatan di SMK kota Blitar menetapkan aspek pengetahuan sebagai salah satu sasaran penilaian dalam pembelajaran Pendidikan Jasmani dan Kesehatan. Guru tersebut melaksanakan penilaian aspek pengetahuan secara resiprokal kepada seluruh siswanya, sebelumnya guru telah mempersiapkan beberapa soal yang kemudian diberikan kepada seluruh siswa. Akan tetapi, secara keseluruhan guru Pendidikan Jasmani dan Kesehatan memberikan nilai aspek pengetahuan secara langsung tidak menunjukkan proses yang telah dijelaskan sebelumnya pada dokumen rancangan pelaksanaan 
pembelajaran (RPP), pada dokumen guru tersebut diterangkan bahwa aspek penilaian pengetahuan memiliki beberapa soal dan juga proses menganalisis nilai pengetahuan dari beberapa soal yang telah diberikan kepada siswa, hasil dari soal yang telah diberikan kepada seluruh siswa dan juga proses analisis penilaian aspek pengetahuan tersebut tidak muncul pada dokumen penilaian yang dimiliki masing-masing guru Pendidikan Jasmani dan Kesehatan di SMK kota Blitar.

Seluruh guru Pendidikan Jasmani dan Kesehatan di SMK kota Blitar menetapkan aspek keterampilan sebagai salah satu sasaran penilaian dalam pembelajaran Pendidikan Jasmani dan Kesehatan disamping aspek sikap dan pengetahuan. Guru tersebut melaksanakan penilaian aspek keterampilan dengan cara pemberian tes praktik atau unjuk kerja kepada seluruh siswanya bedasarkan materi yang telah diajarkan, sebelumnya guru telah mempersiapkan instrumen tes praktik atau unjuk kerja pada materi yang diujikan kepada seluruh siswanya. Akan tetapi, secara guru Pendidikan Jasmani dan Kesehatan tersebut memberikan nilai pada aspek keterampilan secara langsung tidak menujukan proses yang telah dijelaskan sebelumnya pada dokumen rancangan pelaksanaan pembelajaran (RPP), pada dokumen guru tersebut diterangkan bahwa aspek penilaian keterampilan memiliki beberapa indikator penilaian dan juga proses menganalisis nilai keterampilan dari beberapa indikator yang telah ditetapkan oleh guru, hasil dari tiap indikator penilaian aspek keterampilan setiap siswa dan juga proses analisis penilaian aspek keterampilan tersebut tidak muncul pada dokumen penilaian yang dimiliki masing-masing guru Pendidikan Jasmani dan Kesehatan di SMK kota Blitar.

Seluruh guru Pendidikan Jasmani dan Kesehatan di SMK kota Blitar memberikan nilai akhir sebagai nilai rapor siswa pada pembelajaran Pendidikan Jasmani dan Kesehatan, seluruh guru menetapkan nilai akhir siswa berdasarkan nilia-nilai yang diperoleh dari setiap aspek penilaian (aspek sikap, pengetahuan, dan keterampilan) dari ketiga aspek tersebut sebelumnya guru telah menetapkan bobot dari masing-masing aspek penilaian dan terdapat tiga sekolah yang menetapkan nilai akhir siswa dengan ditambahkan hasil penilaian UTS dan UAS. Selain hal tersebut, guru juga telah merencanakan analisis penetapan nilai akhir seluruh siswa, tetapi hanya tiga dari tujuh sekolah yang merencanakan analisis penilaian sesuai dengan masing-masing bobot yang telah ditetapkan oleh masing-masing guru tersebut, sisanya empat sekolah merencanakan analisis penilaian menggunakan rumus rerata dari ketiga aspek penilaian (aspek sikap, aspek pengetahuan dan aspek keterampilan). Pada saat penetapan nilai akhir siswa seluruh guru Pendidikan Jasmani dan Kesehatan di SMK kota Blitar melakukan analisis penilaian akhir sesuai dengan perencanaan yang telah dibuat sebelumnya.

Perlu diadakan pelatihan bagi guru Pendidikan Jasmani dan Kesehatan, khususnya pada segi penilaian pembelajaran. Perlunya peningkatan MGMP bagi guru Pendidikan Jasmani agar terjalin komunikasi dan kerjasama yang baik untuk merumuskan atau menentukan instrumen penilaian yang sesuai dengan tujuan pembelajaran dan karakteristik siswa di masing-masing sekolah. Bagi guru Pendidikan Jasmani dan Kesehatan, diperlukan pengembangan diri untuk menambah wawasan dalam melakukan penilaian khususnya pada tahap analisis penilaian siswa, guru dapat belajar menggunakan sumber-sumber yang ada baik itu dari hasil penelitian, buku, video pembelajaran yang terbaru. Guru Pendidikan Jasmani dan Kesehatan, agar senantiasa membangun kedisiplinan diri, terutama pada proses penilaian siswa dan memanfaatkan waktu luang di sekolah untuk hal-hal yang bermanfaat bagi kualitas kinerjanya.

Guru Pendidikan Jasmani dan Kesehatan harus selalu melakukan pengecekan terhadap lingkungan maupun sarana prasarana yang digunakan untuk melaksanakan penilaian. Perlu adanya kreativitas guru dalam proses penilaian siswa, yakni seorang guru disarankan untuk selalu menyesuaikan instrumen yang telah dibuat pada saat MGMP terhadap lingkungan dan sarana prasarana sekolah sehingga tujuan hasil belajar dapat tercapai. Perlunya kejujuran seorang guru untuk memberikan nilai pada siswa, hal ini juga dapat memengaruhi tujuan untuk menggambarkan hasil belajar dapat tercapai. Perlu adanya pengawasan bagi pihak yang terkait terhadap kenerja guru Pendidikan Jasmani dan Kesehatan khususnya pada tahap penilaian diharapkan hal tersebut dapat meningkatkan atau memperbaiki kinerja guru. Bagi pemerintah daerah, perlu dilaksanakan program peningkatan sumber belajar bagi guru khusnya guru Pendidikan Jamani dan Kesehatan, guna untuk mengoptimalkan kinerja guru. Hal ini dapat dilakukan dengan car menyediakan berbagai sumber belajar yang telah diperbarui. Bagi pihak yang terkait, perlu dilakukan pengawasan secara konsisten terhadap pelatihan atau MGMP guru Pendidikan Jasmani dan Kesehatan untuk memantau keberhasilan pelatihan yang telah dilakukan.

\section{DAFTAR RUJUKAN}

Allen, K. N., \& Friedman, B. D. (2010). Affective Learning : A Taxonomy for Teaching Social Work Values. Journal of Social Work Values and Ethics, 7(2), 1-12.

Baan, A. B. (2012). The Development of Physical Education Teacher Professional Standards Competency. Journal of Physical Education and Sports, 1(1).

Basuki, I., \& Hariyanto. (2016). Asesmen Pembelajaran. Bandung: PT Remaja Rosdakarya.

Eraslan, A. (2013). Teachers' Reflections on the Implementation of the New Elementary School Mathematics Curriculum in Turkey Yeni İlköğretim Matematik Programı Hakkında. Hacettepe Üniversitesi Egitim Fakültesi Dergisi, 28(2), $152-165$.

Gaytan, J., \& Mcewen, B. C. (2007). Effective Online Instructional and Assessment Strategies. The American Journal of Distance Education, 21(3), 117-132.

Hanna, G. S., \& Dettmer, P. A. (2003). Assessment for Effective Teaching: Using Context-Adaptive Planning. United States of America: Pearson Education.

Haryati, M. (2008). Model \& Teknik Penilaian pada Tingkat Satuan Pendidikan. Jakarta: Gaung Persada Press. 
Kankam, B., Bordoh, A., Eshun, I., Bassaw, T. K., \& Korang, F. Y. (2015). Teachers 'Perception of Authentic Assessment Techniques Practice in Social Studies Lessons in Senior High Schools in Ghana. 1(4), 62-68.

Lleixà, T., González-Arévalo, C., \& Braz-Vieira, M. (2016). Integrating Key Competences in School Physical Education programmes. European Physical Education Review, 22(4), 506-525. https://doi.org/10.1177/1356336X15621497

Markle, B. R., \& Banion, T. O. (2014). Assessing Affective Factors to Improve Retention and Completion. Learning Abstracts, $17(11), 1-16$.

Peraturan Menteri Pendidikan dan Kebudayaan. (2016). Standart Penilaian. Jakarta: Permendikbud.

Popham, W. J. (2009). Instruction That Up Measures Up. Virginia: ASCD.

Stufflebeam, D. L., \& Coryn, C. L. S. (2014). Evaluation, Theory, Models, and Applications. Second Edition. San Fransisco: Jossey-Bass.

Sudjana, N. (2014). Penilaian Hasil Proses Belajar Mengajar. Bandung: Remaja Rosdakarya.

Uno, H. B., \& Koni, S. (2016). Assessment Pembelajaran Salah Satu bagian Penting dari Pelaksanaan Pembelajaran yang tidak dapat Diabaikan adalah Pelaksanaan Penilaian. Jakarta: Bumi Aksara.

Wang, K. M., Wang, P. S., \& Huang, Y. C. (2012). Physical Fitness and Academic Achievement of Elementary School Students: A Cross-Sectional Survey in Southern Taiwan. Journal of Physical Education and Sport, 12(3), 302-309.

Winarno, M. E. (2014). Evaluasi Hasil Pendidikan Jasmani Olahraga dan Kesehatan. Malang: UM Press.

Wood, B. B. (2010). Stake's Countenance Model: Evaluating an Environmental Education Professional Development Course. Journal of Environmental Education, 32(2), 18-27. https://doi.org/10.1080/00958960109599134

Zhang, G., Zeller, N., Griffith, R., Metcalf, D., Williams, J., Shea, C., \& Misulis, K. (2011). Using the Context, Input, Process, and Product Evaluation Model (CIPP) as a Comprhensive Framework to Guide the Planning, Implementation, and Assessment of Service-Learning Programs. Journal of Hihger Education Outreach and Engagement, 15(4), 57-84. 